\title{
Measuring Skill-upgrading in the Dutch Labor Market
}

Citation for published version (APA):

Dupuy, A. (2006). Measuring Skill-upgrading in the Dutch Labor Market. Researchcentrum voor Onderwijs en Arbeidsmarkt, Faculteit der Economische Wetenschappen. ROA Working Papers No. 003E https://doi.org/10.26481/umarow.2006003E

Document status and date:

Published: 01/01/2006

DOI:

10.26481/umarow.2006003E

Document Version:

Publisher's PDF, also known as Version of record

\section{Please check the document version of this publication:}

- A submitted manuscript is the version of the article upon submission and before peer-review. There can be important differences between the submitted version and the official published version of record.

People interested in the research are advised to contact the author for the final version of the publication, or visit the DOI to the publisher's website.

- The final author version and the galley proof are versions of the publication after peer review.

- The final published version features the final layout of the paper including the volume, issue and page numbers.

Link to publication

\footnotetext{
General rights rights.

- You may freely distribute the URL identifying the publication in the public portal. please follow below link for the End User Agreement:

www.umlib.nl/taverne-license

Take down policy

If you believe that this document breaches copyright please contact us at:

repository@maastrichtuniversity.nl

providing details and we will investigate your claim.
}

Copyright and moral rights for the publications made accessible in the public portal are retained by the authors and/or other copyright owners and it is a condition of accessing publications that users recognise and abide by the legal requirements associated with these

- Users may download and print one copy of any publication from the public portal for the purpose of private study or research.

- You may not further distribute the material or use it for any profit-making activity or commercial gain

If the publication is distributed under the terms of Article $25 \mathrm{fa}$ of the Dutch Copyright Act, indicated by the "Taverne" license above, 


\title{
Measuring Skill-upgrading in the Dutch Labor Market \\ ROA-W-2006/3E
}

\author{
Arnaud Dupuy
}

Research Centre for Education and the Labour Market

Faculty of Economics and Business Administration

Maastricht University

Maastricht, May 2006 
ISBN-10: 90-5321-435-6

ISBN-13: 978-90-5321-435-0

Sec06.035.pdf 


\section{Contents}

$\begin{array}{ll}\text { Abstract } & 1\end{array}$

1 Introduction 1

2 Methodology 4

3 Conclusion 9

$\begin{array}{lr}\text { References } & 10\end{array}$ 



\title{
Measuring Skill-upgrading in the Dutch Labor Market*
}

\author{
Arnaud Dupuy
}

\begin{abstract}
An important factor of shifts in the skills composition of the workforce is the upgrading of the qualifications demanded in the various jobs in the economy, the so-called skill-upgrading. This skill-upgrading is principally caused by the development of new technologies that demand more or different skills to be efficiently operated or by organizational changes that lead to increase the skills demanded to perfom the tasks of the various occupations. Drawing from the microeconomic foundations of demand shifts, this paper presents an empirical methodology to estimate the speed of skill-upgrading in different periods.
\end{abstract}

\section{Introduction}

An important factor of shifts in the skills composition of the workforce is the upgrading of the qualifications demanded in the various jobs in the economy, the so-called skill-upgrading. This skill-upgrading is principally caused by the development of new technologies that demand more or different skills to be efficiently operated or by organizational changes that lead to increase the skills demanded to perform the tasks of the various occupations.

To illustrate this skill-upgrading, Figure 1 indicates for the Netherlands the evolution of the demand for workers in 5 different educational levels over time at constant wage structure and supply of workers by educational level. The evolution of the demand for workers by educational levels is therefore

\footnotetext{
*I thank Lex Borghans and Frank Cörvers for their comments on earlier drafts of this paper.
} 
purely driven by technological and organizational changes. Suppose that in 1980, the demand for workers with primary education (BO), lower secondary education (VMBO), upper secondary education (MBO), higher vocational education (HBO) and university education (WO) is 100. The full lines correspond to the measure of skill-upgrading as measured using employment data by education and occupation for the period 1979-1992. Given the estimated upgrading coefficients in the $80 \mathrm{~s}$, the demand for college graduates would have increased at a average annual rate of $2.2 \%$ while the demand for workers with primary education would have decreased at a average annual rate of $4.5 \%$. At constant speed of skill-upgrading, the demand for university graduates would have doubled in 2010 (from 100 to 190) whereas the demand for workers with primary education would be four times smaller than the 1980 demand (from 100 to 26).

However, the structural changes that take place in the labor market do not need to be constant over time. These structural changes are caused by i) the introduction of new technologies that are relatively more complementary with some types skills than others and ii) changes in the price of capital when capital is complementary with skilled workers of workers with specific skills in production. This means that in periods of few changes in technology or stable price of capital, there will be no or few skill-upgrading.

Recent developments in the labor market show evidence that not only the speed of skill-upgrading is lower than in the 80s but also the nature of skill-upgrading has shifted from generic to specific skills. A very interesting example of which is found in the banking sector. ${ }^{1}$ Since ATM's perform tasks that were previously performed by low skilled workers, the direct effect of the introduction of ATM's was to decrease the demand for low skilled workers in the banking sector and indeed, between 1984- the introduction of the ATM in the banking sector in the US- and 1995, the employment of low skilled workers dropped by 41,000 in the banking sector. However, the use of new technologies was complemented by a work reorganization that led tellers (the old job title "Teller" has been replaced by a new job title "Customer Service

\footnotetext{
${ }^{1}$ Hunter, L., A. Bernhardt, K. Hughes, and E. Skuratowicz (2001) give a very detailed picture of the effects of the introduction of ATM's in the bank sector. They not only consider the effect of the introduction of this new technology on employment within the bank sector but also consider the effect reorganization that followed as a direct consequence the introduction of ATM's. See also van Reenen and Caroli (2001). Therein the authors show that organizational changes complement technological changes.
} 
Representative") to take over routine tasks ${ }^{2}$ previously performed by Personal Bankers so that Personal Bankers could focus on sales exclusively. As a result, the number of employed tellers stabilized rather than dramatically decreased since the mid-90s. ${ }^{3}$ This example clearly indicates that although new technologies might lead to rapid skill-upgrading, organizational changes that complement these new technologies might contribute to slowdown the skill-upgrading.

To illustrate these changes in the speed of skill-upgrading in the Netherlands, we estimated the skill-upgrading coefficients using recent data on employment by education and occupation for the period 1996-2003. We then apply these new coefficients to the demand for workers with the various educational levels from 1999 on (the mid-point of the period for which these new coefficients are estimated). The dotted lines clearly indicate that the speed of skill-upgrading has decreased significantly since 1999 compared to the 80s and 90s. The demand for university graduates increased at an annual rate of 0.3 percent only between 1999 and 2010 whereas the demand for workers with primary education decreased at an annual rate of 0.2 percent only.

Note that due to technological and organizational changes, the demand for higher vocational graduates will rise more rapidly than the demand for university graduates (yearly differential growth of 0.9\%) between 1999 and 2010. This is in sharp contrast with the skill-upgrading observed in the $80 \mathrm{~s}$ and 90 s that saw the relative demand for university graduates to higher vocational graduates grow at a yearly rate of $0.7 \%$. This shows some evidence that the current technological and organizational changes demand relatively more specific and applied skills than generic skills in contrast with the technological and organizational changes of the $80 \mathrm{~s}$ and $90 \mathrm{~s}$. This is consistent with Nelson and Phelps's (1966) hypothesis, see also more recently the study by Greenwood and Yorokoglu (1997), that workers with generic skills (university graduates) have a comparative advantage in implementing and adopting new technologies. Technological changes are therefore followed by a transition period during which a growing proportion of workers with generic skills are assigned to "new" tasks that consist of experimenting, developing and implementing routines in order to use these new technologies. This transition period is characterized by an acceleration of the demand for skilled workers

\footnotetext{
${ }^{2}$ For instance, changing addresses, issuing cards and adding new accounts etc. Note that these tasks are impossibly done by machines and rather easily performed by humans.

${ }^{3}$ Note that a partial explanation for the Tellers employment stabilization is a steady decrease of the average number of hours worked.
} 
and a fast growing skill premium but a slowdown in labor productivity. As routines become available, workers with specific and applied skills start using the new technology in their job. The demand for specific and applied skills increases compared to the demand for generic skills.

\section{Methodology}

Suppose aggregate output in the economy, say $Y_{t}$, is produced by combining intermediate occupational outputs, say $Y_{j}$ with $j=1, \ldots, N_{j}$ where $N_{j}$ is the number of distinct occupations in the economy, with a CES technology:

$$
Y_{t}=\left(\sum_{j} \delta_{j t} Y_{j t}^{\beta}\right)^{1 / \beta}
$$

where $\delta_{j t}$ are efficiency units of occupational output $j$ at time $t$ and $\sigma=\frac{1}{1-\beta}$ is the ease to substitute intermediate outputs.

The occupational output is produced by combining workers with different educational backgrounds in various proportions as follows:

$$
Y_{j t}=\left(\sum_{i} \lambda_{i j t} L_{i j t}^{\beta_{e}}\right)^{1 / \beta_{e}}
$$

where $\lambda_{i j t}$ are efficiency units of workers with education $i$ in occupation $j$ at time $t$ and $\sigma_{e}=\frac{1}{1-\beta_{e}}$ is the ease to substitute workers with various educational backgrounds within occupations. $L_{i j t}$ is employment in occupation $j$ of workers with education $i$ at time $t$.

Equating marginal productivity to wages by education $w_{i t}$, that is assuming perfect competition in the labor market, yields the equilibrium employment level by occupation and education as:

$$
L_{i j t}=Y_{t}\left(U C_{t}\left(w_{t}\right)\right)^{\sigma}\left(U C_{j t}\left(w_{t}\right)\right)^{\sigma_{e}-\sigma} \delta_{j t}^{\sigma}\left(\frac{\lambda_{i j t}}{w_{i t}}\right)^{\sigma_{e}} \forall i, j
$$

with 


$$
U C\left(w_{t}\right)=\left(\sum_{j} \delta_{j t}^{\sigma}\left(U C_{j t}\left(w_{t}\right)\right)^{1-\sigma}\right)^{1 /(1-\sigma)}
$$

and

$$
U C_{j t}\left(w_{t}\right)=\left(\sum_{j} \lambda_{i j t}^{\sigma_{e}} w_{i t}^{1-\sigma_{e}}\right)^{1 /\left(1-\sigma_{e}\right)}
$$

where $U C$ stands for unit costs and $w_{t}=\left\langle w_{1 t}, \ldots, w_{N_{i} t}\right\rangle$ where $N_{i}$ indicates the number of education.

Suppose technology is constant so that $\delta$ and $\lambda$ are constant over time. Changes in $(\log )$ employment of workers with education $i$ in occupation $j$ over time are bi-proportional and given by:

$$
\begin{aligned}
\Delta \ln L_{i j t} & =\Delta \ln Y_{t}+\sigma \Delta \ln \left(U C\left(w_{t}\right)\right)+\left(\sigma_{e}-\sigma\right) \Delta \ln U C_{j t}\left(w_{t}\right)-\sigma_{e} \Delta \ln w_{i t} \\
& =\Delta \ln Y_{t}+\sigma \Delta \ln \left(U C\left(w_{t}\right)\right)+\ln R_{j}+\ln S_{i}
\end{aligned}
$$

This means that when technology is constant over time, changes in the allocation of workers with education $i$ in occupation $j$ (that can only be induced by changes in the wage structure) can be measured using the RAS method. ${ }^{4}$

Suppose now that technology does change over time but only $\delta_{j}$ may change. These types of shifts are neutral in terms of education but nonneutral in terms of occupational output. By neutral in terms of education, we mean that the sectorial or technical changes do not complement nor substitute workers with some particular education within occupations. All workers, irrespective of their education, are affected the same way. Think of a new machine that enhances marginal productivity in occupation $i$ at $t+1$ and could be operated as productively by any type of worker. The changes in the $(\log )$ employment of workers with education $i$ in occupation $j$ are still bi-proportional and read as:

\footnotetext{
${ }^{4}$ See Stone and Brown (1964), Evens and Lindley (1973), Kadas and Klafzky (1976), van Eijs and Borghans (1996) and Dupuy and Borghans (2005).
} 


$$
\begin{aligned}
\Delta \ln L_{i j t}= & \Delta \ln Y_{t}+\sigma \Delta \ln \left(U C\left(w_{t}\right)\right)+\left(\sigma_{e}-\sigma\right) \Delta \ln U C_{j t}\left(w_{t}\right) \\
& +\sigma \Delta \ln \delta_{j t}-\sigma_{e} \Delta \ln w_{i t} \\
= & \Delta \ln Y_{t}+\sigma \Delta \ln \left(U C\left(w_{t}\right)\right)+\ln R_{j}^{*}+\ln S_{i}
\end{aligned}
$$

However, the occupational component is different from 0 even at constant wage structure, i.e. $w_{i t}=w_{i t-1}$ for all $i$, because of the term $\sigma \Delta \ln \delta_{j t}$ in $\ln R_{j}^{*}$. Hence, given constant wage structure, shifts in the demand for workers has the so-called fixed coefficient structure.

$$
L_{i j t} \equiv F C_{i j t}=L_{i j t-1} \times \frac{L_{. j t}}{L_{. j t-1}}
$$

where $F C_{i j t}$ is the employment of workers with education $i$ in occupation $j$ were the wage structure constant and technology neutral in terms of education but non neutral in terms of occupations between $t$ and $t-1$.

However, technical changes in general may be non-neutral to educational groups of workers within occupations and therefore $\lambda_{i j}$ may vary over time. The changes in $(\log )$ relative demand for workers with education $i$ in occupation $j$ are not bi-proportional anymore and read as:

$$
\begin{aligned}
\Delta \ln L_{i j t}= & \Delta \ln Y_{t}+\sigma \Delta \ln \left(U C\left(w_{t}\right)\right)+\left(\sigma_{e}-\sigma\right) \Delta \ln U C_{j t}\left(w_{t}\right) \\
& +\sigma \Delta \ln \delta_{j t}-\sigma_{e} \Delta \ln w_{i t}+\sigma_{e} \Delta \ln \lambda_{i j t} \\
= & \ln R_{j}^{*}+\ln S_{i}+\ln A_{i j}
\end{aligned}
$$

This means that, at constant wage structure and assuming that the loglinear relationship between the non-neutral technical changes and changes in employment are accurately approximated by a linear relationship, shifts in the demand for workers, can be expressed as follows.

$$
L_{i j t} \equiv D_{i j t}=F C_{i j t}+c_{i j t}
$$

where $c_{i j t}$ is a term indicating skill-biased technical and organizational changes. In the empirical analysis, the change in $c_{i j}$, i.e. $c_{i j t}-c_{i j t-1}=u_{i j}$ is assumed to be constant at least within subperiods (constant between 1979-1992, as in 
early expansion demand forecasts, ${ }^{5}$ and constant between 1996 and 2003 in the expansion demand forecasts for the period 2004-2010 ${ }^{6}$ ).

Summing up equation 2 over $j$, the demand for workers with education $i$ reads as:

$$
D_{i t}=F C_{i t}+C_{i t}
$$

Summing up equation 1 over $i$ leads to:

$$
\begin{aligned}
D_{. j t} & =F C_{j t}+C_{j t} \\
& =L_{. j t}+C_{j t} \\
& \Leftrightarrow \\
C_{j t} & =0
\end{aligned}
$$

Equation 2 describes demand at time $t$ given the wage structure at time $t-1$ that is given the supply structure at time $t-1$. Since the supply structure may change over time, there will in general be a gap between demand as depicted in equation 3 and supply. This gap is equal to:

$$
G_{i t}=D_{i t}-S_{i t}
$$

where $S_{i t}=L_{i . t}$.

Employment of workers with education $i$ in occupation $j$ at time $t$ is therefore given by:

$$
\begin{aligned}
L_{i j t} & =D_{i j t}-\alpha_{i j} G_{i t} \\
& \Leftrightarrow \\
L_{i j t}-F C_{i j t} & =c_{i j t}-\alpha_{i j} G_{i t}
\end{aligned}
$$

with $\sum_{j} \alpha_{i j}=1$.

\footnotetext{
${ }^{5}$ See ROA (1995).

${ }^{6}$ See ROA (2005).
} 
Knowing $G_{i t}$ enables the estimation of Equation 4 using OLS techniques to get estimates of $c_{i j t}$ and $\alpha_{i j}$. However, while the set of $\alpha$ parameters are identified through the OLS estimation, only the relative $c$ parameters are identified, not their level, i.e. the sum of the parameters is unknown. This means that setting $C_{i}=0$ for instance, which is equivalent to identifying $G_{i t}$ as $F C_{i t}-S_{i t}$, one can retrieve the conditional estimates of $c_{i j}$ via OLS regression of equation 4. However, one could also have set $C_{i}=C$ (equivalently set $\left.G_{i t}=F C_{i t}+C-S_{i t}\right)$ and retrieve the same relative $c_{i j}$ parameters. To identify $C_{i}$, we need an additional equation.

An interesting possibility is met when there is a relationship between the $\alpha^{\prime} s$ and the $c^{\prime} s$, characterized by the function $c_{i j}=f\left(\alpha_{i j}\right)$. Using the linear approximation to $f$ and denoting $\widetilde{c}_{i j}$ the estimates of $c_{i j}$ conditional on $\widetilde{C}_{i}=\sum \widetilde{c}_{i j}=0$, the $C_{i}$ 's can be identified by regressing $\widetilde{c}_{i j}$ on $\alpha_{i j}$ for all $i$ using OLS techniques: ${ }^{7}$

$$
\widetilde{c}_{i j}=\text { const }_{i j}-\gamma_{i} \alpha_{i j}+e_{i j}
$$

Indeed, summing equation 5 over $j$ yields $\widetilde{C}_{i}=0=\sum_{j} \widehat{c o n s}_{i j}+\widehat{\gamma}_{i}$.

One problem with this estimation is that the $\alpha^{\prime} s$ are estimates of the first step estimation procedure and are therefore measured with errors. As suggested in Judge et al. (1985), IV estimation techniques can be used to overcome this problem. One would proceeds in two steps:

1. Construct an instrument for $\alpha^{\prime} s$, for instance a variable containing the rank of the $\alpha^{\prime} s$, and regress the $\alpha^{\prime} s$ on its instrument. Derive the insample prediction of the $\alpha^{\prime} s, \widehat{\alpha}=\left(1: \operatorname{Rank}_{\alpha}\right) \widehat{\beta}$ where 1 is a vector that contains ones and $\operatorname{Rank}_{\alpha}$ a variable containing the rank of the $\alpha^{\prime} s$.

2. Replace $\alpha$ by $\widehat{\alpha}$ and use LS techniques to estimate equation 5 .

The estimation results for the Netherlands using the Labour Force Survey data from 1979 to $2003^{8}$ and 128 distinct occupations are presented in Table 1. These upgrading coefficients have been used to derive Figure 1 discussed in the introduction. The striking result is the deceleration of the speed of

\footnotetext{
${ }^{7}$ There are an infite number of possible shapes for the function indicating the relationship between $c^{\prime} s$ and $\alpha^{\prime} s$ that satisfy $\widetilde{C}_{i}=0=\sum_{j} f\left(\widehat{c}_{i j}, \widehat{\gamma}_{i}\right)$.

${ }^{8}$ The Labour Force Survey was first conducted every two years from 1979 to 1988. Since 1988 , it is conducted on a yearly basis.
} 
skill upgrading since the mid 90s at all levels of education relative to primary education and the twist between higher vocational graduates and university graduates, from positive shifts in the relative demand for university graduates at a yearly rate of $1.15 \%$ to negative shifts at a yearly rate of $-0.59 \%$.

\section{Conclusion}

An important factor of shifts in the skills composition of the workforce is the upgrading of the qualifications demanded in the various jobs in the economy, the so-called skill-upgrading. This skill-upgrading is principally caused by the development of new technologies that demand more or different skills to be efficiently operated or by organizational changes that lead to an increase of the skills demanded to perform the tasks of the various occupations. Drawing microeconomic foundations of demand shifts from production functions, this paper presented an empirical methodology to estimate the speed of skill upgrading in different periods.

The results of this paper provide empirical evidence that the structural changes that take place in the Dutch labor market are not constant over time. The results clearly indicate that the speed of skill-upgrading in the Netherlands has decreased significantly since the mid 90s compared to the 80s. While the demand for college graduates increased at an annual rate of 2.6 percent only between 1979 and 1992 and the demand for workers with primary education decreased at an annual rate of 4.5 percent, the demand for university graduates increased at an annual rate of 0.3 percent only between 1996 and 2003 while the demand for workers with primary education decreased at an annual rate of 0.2 percent only.

The methodology presented in this paper could be improved in several directions. First, so far we assume that the log-linear relationship between the non-neutral technical changes and changes in employment are accurately approximated by a linear relationship. This is a strong assumption that might bias the estimates of skill-upgrading. Particular attention should be paid to the implications of this assumption and weaker alternatives should be proposed and investigated. Second, the identification of the $C_{i}$ parameters requires additional information. So far we imposed more structure, i.e. a linear relationship between $c_{i j}$ and $\alpha_{i j}$, to the model to being able to identify these parameters. Alternative approaches should be proposed and the relative efficiencies of the various methods should be investigated. 


\section{References}

Dupuy, A., And L. Borghans (2005): "Supply and demand, allocation and wage inequality: an international comparison," Applied Economics, 37(9), 1073-1088.

Evans, G., And R. Lindley (1973): "The Use of RAS and Related Models in Manpower Forecasting," Economics of Planning, 13(1-2), 53-73.

Greenwood, J., And M. Yorukoglu (1997): “1974,” Carnegie-Rochester Conference Series on Public Policy, 46, 49-95.

Hunter, L., A. Bernhardt, K. Hughes, and E. Skuratowicz (2001): "It's Not Just the ATMs: Technology, Firm Strategies, Jobs, and Earnings in Retail Banking," Industrial and Labor Relations Review, 54(2A), 40224 .

Judge, G., W. Griffiths, R. Hill, H. Lütkepohl, and T.-C. Lee (1985): The Theory and Practice of Econometrics. New York: Wiley, 2nd edn.

Kadas, S., And E. Klafzky (1976): "Estimation of the Parameters in the Gravity Model for Trip Distribution: A New Method and Solution Algorithm," Regional Science and Urban Economics, 6(4), 439-57.

Nelson, R. R., and E. S. Phelps (1966): "Investment in Humans, Technology Diffusion and Economic Growth," American Economic Review, Papers and Proceedings, 56(2), 69-75.

ROA (1995): "The Labour Market by Education and Occupation to 2000," ROA Report Series, ROA-R-1995-3E.

(2005): "De Arbeidsmarkt Naar Opleiding En Beroep Tot 2010," ROA Report Series, ROA-R-2005/9.

Stone, R., And A. Brown (1964): A Computable Model of Economic Growth, vol. 1 of the series "A Programme for Growth". London: Chapman and Hall.

Van Eijs, P., And L. Borghans (1996): "The Use of RAS in Manpower Forecasting: A Microeconomic Approach," Economic Modelling, 13, 25787. 
Van Reenen, J., and E. Caroli (2001): "Skill-Biased Organisational Change? Evidence from British and French Establishments.," Quarterly Journal of Economics, 116(4), 1449-92. 
Skill-upgrading by educational level:

Steady (full lines) or deceleration (dotted lines)?

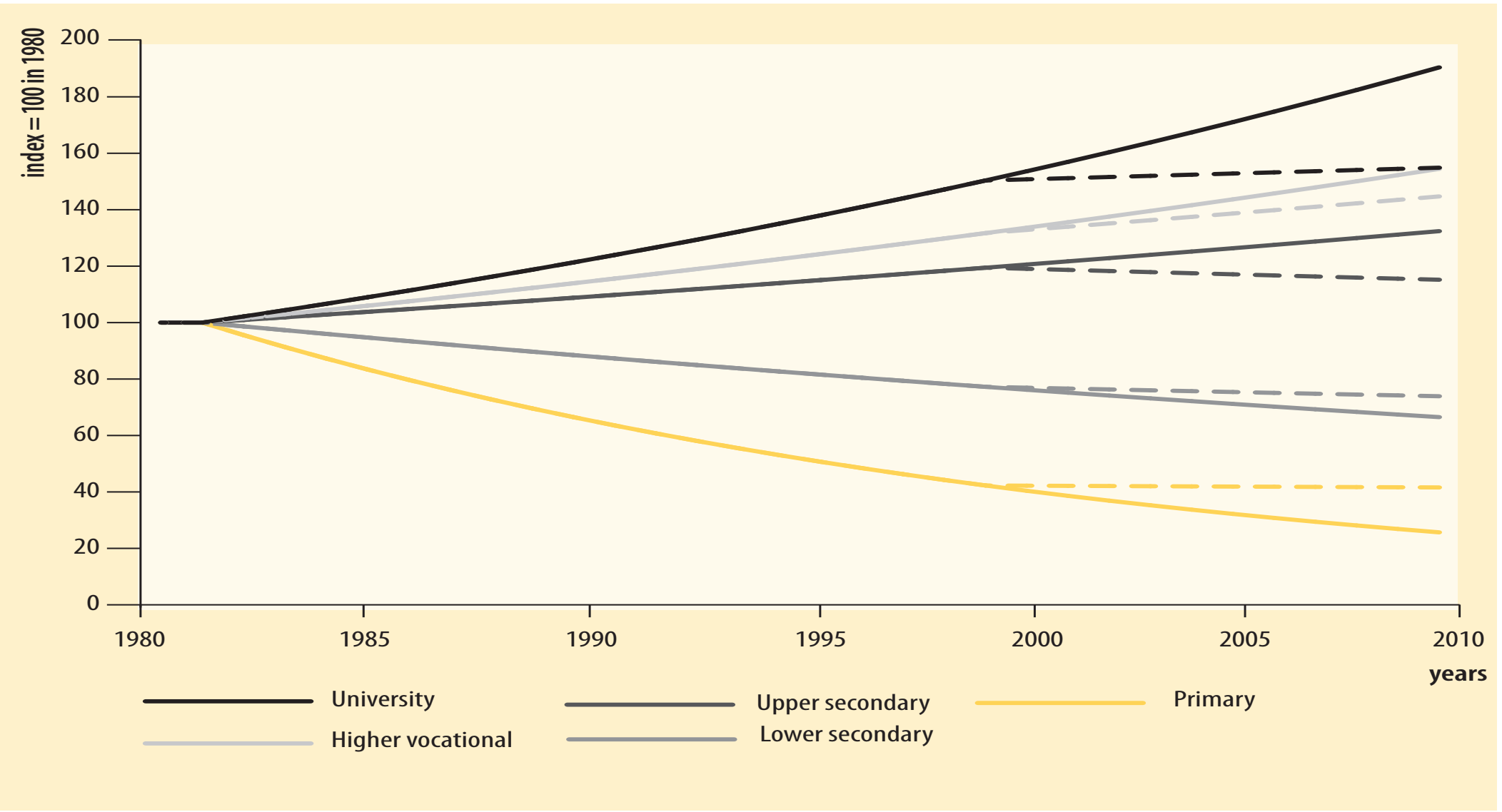

Figure 1: Steady demand or deceleration? 
Table 1: Skill-upgrading coefficients for the periods 1979-1992 and 1996-2003.

\begin{tabular}{l|rr|rr}
\hline \hline Periods & $1979-1992$ & Relative & $1996-2003$ & Relative \\
\hline Education & $\%$ & & $\%$ & \\
Primary & -4.48 & & -0.15 & \\
Lower secondary & -1.08 & $3 . \overline{40}$ & -0.40 & $-0 . \overline{25}$ \\
Upper secondary & 0.94 & 5.42 & -0.33 & -0.18 \\
Higher vocational & 1.46 & 5.94 & 0.86 & 1.01 \\
University & 2.61 & 7.09 & 0.27 & 0.42 \\
& & & & \\
\hline \hline
\end{tabular}

